\title{
Nawarstwienia kulturowe po południowej stronie kościoła św. Jakuba w Toruniu w świetle badań archeologiczno-architektonicznych $\mathrm{z}$ lat 2008-2015*
}

Jakub Rychlik

Toruń

\section{Badania archeologiczno-architektoniczne z lat 2008-2015}

Toruński kościół św. Jakuba od dawna budzi zainteresowanie badaczy specjalizujących się w różnych dziedzinach nauki: historii, architektury, historii sztuki i konserwacji zabytków oraz archeologii. Przedstawiciele ostatniej z wymienionych dyscyplin badali otoczenie kościoła w latach 2008-2015 ${ }^{1}$. Funkcję kierownika prac pełniła dr hab. Krystyna Sulkowska-Tuszyńska, prof. UMK, a członkowie ekspedycji rekrutowali się spośród studentów Instytutu Archeologii UMK i wolontariuszy. Archeolodzy badali wykopaliskowo teren wokół kościoła, zakładając łącznie 17 wykopów służących realizacji licznych celów naukowych, z których najważniejsze stanowiły: wszechstronne rozpoznanie terenu wokół kościoła i dawnego klasztoru benedyktynek, sprawdzenie istnienia w tym miejscu wcześniejszej świątyni (przed 1309 r.) i innych zabudowań oraz przebadanie fundamentów budowli. Do pozostałych zamierzeń archeologów należały: weryfikacja zmian dokonanych w planie

\footnotetext{
* Podstawą niniejszego artykułu jest praca magisterska pt. „Analiza nawarstwień kulturowych po południowej stronie kościoła św. Jakuba w Toruniu (badania w latach 2008-2015)", napisana pod kierunkiem dr hab. Krystyny Sulkowskiej-Tuszyńskiej, prof. UMK, i obroniona w Instytucie Archeologii UMK w Toruniu.

${ }^{1}$ Należy zaznaczyć, że jak dotąd wnętrze kościoła nie zostało poddane badaniom archeologicznym, mimo że prowadzono w nim remont prezbiterium i posadzki.
} 
budowy kościoła w trakcie jej realizacji, próba odnalezienia reliktów dawnego budownictwa oraz sprawdzenie przebiegu korytarza łączącego klasztor z kościołem. Dzięki badaniom możliwe stało się pogłębienie wiedzy na temat kultury toruńskich mieszczan na podstawie jej materialnych śladów, m.in. znalezisk pochodzących z grobów. Od pierwszego sezonu badań przy kościele św. Jakuba w 2008 r. numeracja wykopów jest ciągła (numer wykopu łamany przez rok, np. W-12/13). Prace wykopaliskowe prowadzono poprzez eksplorację warstw mechanicznych o średniej miąższości $15 \mathrm{~cm}$ i grobów. Wydobytą ziemię sprawdzano $\mathrm{w}$ dwóch etapach - bezpośrednio podczas eksploracji oraz przed przerzuceniem jej na hałdę. Niejednokrotnie zawartość najniższych, nieprzemieszanych poziomów przesiewano przez sito. Każdy pochówek, zachowany choćby częściowo w układzie anatomicznym, wydobywano po dokładnej analizie jamy grobowej i ułożenia szczątków, a kości po oczyszczeniu przekazywane były do badań antropologicznych ${ }^{2}$. Wszystkie groby zostały opisane w dziennikach polowych wykopów i naszkicowane $\mathrm{w}$ inwentarzu grobów. Wszelkie informacje na temat warstw, odkrytych w nich reliktów architektury, zabytków, a także szkice umieszczane były w dziennikach polowych przez osoby odpowiedzialne za bieżącą eksplorację w wykopach, będące pod nadzorem doktorantów. Wydobyte zabytki wstępnie zabezpieczano już na stanowisku, a po przewiezieniu do Instytutu Archeologii UMK poddane były one dalszym zabiegom konserwatorskim. Każdego dnia wykonywano fotografie wszystkich warstw, pomiary wysokości teodolitem i niwelatorem oraz szkice warstw. Na koniec badań sporządzono dokumentację fotograficzną i rysunkową profili wszystkich wykopów, a także rzuty płaskie i plany sytuacyjne w skali 1:20 i 1:10.

\section{Zarys historii kościoła i klasztoru}

Początek dziejów kościoła św. Jakuba w Toruniu większość badaczy określa na rok 1309, w którym rozpoczęto budowę jego ceglanego prez-

\footnotetext{
${ }^{2}$ Badania antropologiczne kości odkrytych w latach 2008-2013 przeprowadził dr Jarosław Bednarek z Zakładu Genetyki Molekularnej i Sądowej Collegium Medicum UMK w Bydgoszczy; szczątki ludzkie pochodzące z badań w 2015 r. badane były wyłącznie na podstawie dokumentacji fotograficznej.
} 


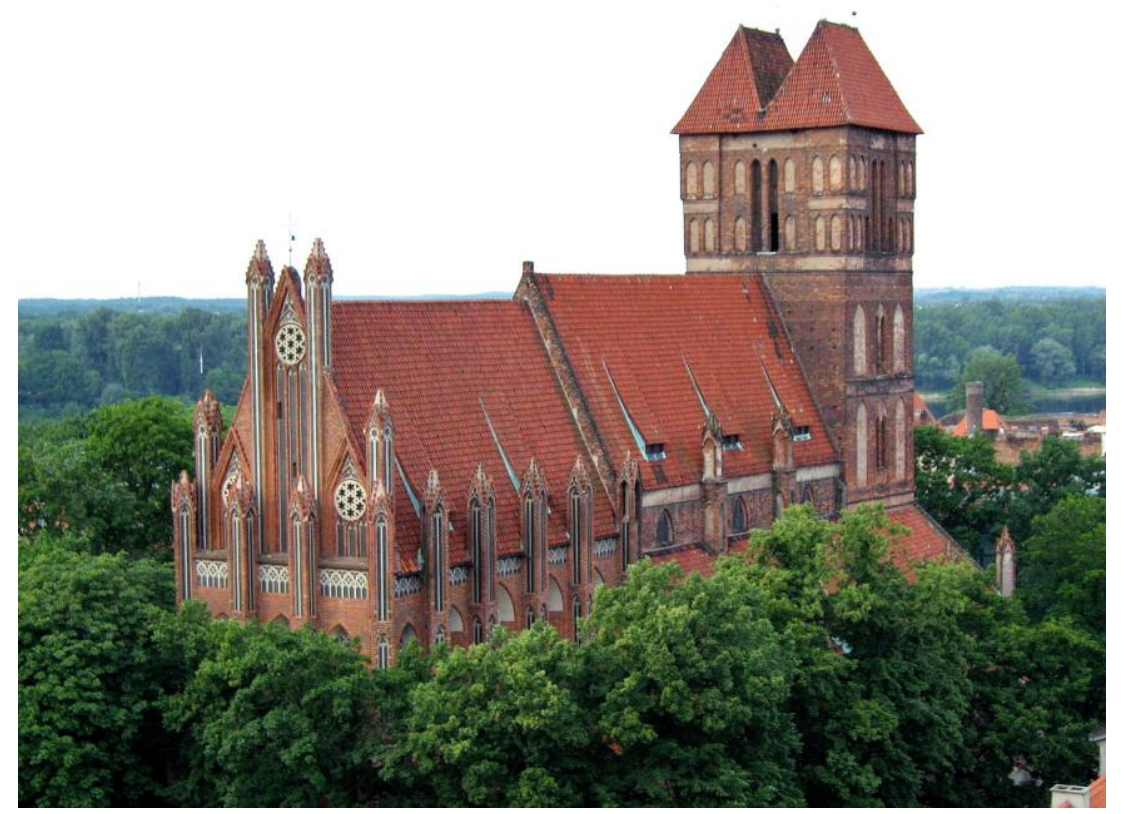

Ryc. 1. Kościół św. Jakuba w Toruniu. Widok od północnego wschodu (źródło: https://pl.wikipedia.org/wiki/Kościół_św._Jakuba_w_Toruniu\#/ media/File:Kosciol_sw._Jakuba_w_Toruniu.jpg)

biterium. Jednak zapewne idea wzniesienia kościoła pojawiła się znacznie wcześniej, w momencie planowania urbanistycznego Nowego Miasta Torunia, lokowanego w 1264 r. (Krantz-Domasłowska, Domasłowski 2001, s. 8-9). Wiadomości źródłowe na temat średniowiecznych dziejów kościoła św. Jakuba są wyjątkowo ubogie. Pewna grupa badaczy uważa, że w miejscu obecnej świątyni znajdowała się pierwotnie inna, mniejsza budowla sakralna, prawdopodobnie drewniana (Sulkowska-Tuszyńska 2010, s. 266-268). Zdaniem Liliany Krantz-Domasłowskiej teren przy północno-wschodniej części rynku przez kilkadziesiąt lat nie mógł pozostawać pusty. Z całą pewnością kwestię bezsporną stanowi data rozpoczęcia prac budowlanych przy wznoszeniu gmachu obecnego kościoła, o której świadczy inskrypcja wokół prezbiterium, upamiętniająca położenie kamienia węgielnego przez biskupa 
chełmińskiego Hermana (Krantz-Domasłowska, Domasłowski 2001, s. 50). Jako datę założenia miejscowej parafii przyjmuje się rok 1304, o czym jest mowa w jednym z XVIII-wiecznych protokołów wizytacyjnych. Jest to świadectwo funkcjonowania na tym terenie wcześniejszej budowli, poprzedzającej obecnie istniejącą (Krantz-Domasłowska, Domasłowski 2001, s. 10).

Według historyków budowa kościoła św. Jakuba trwała do połowy lat czterdziestych XIV w., a dokumentami potwierdzającymi ten fakt są zapisy dotyczące prawa patronatu nad kościołem, przyznanego zgromadzeniu cysterek $\mathrm{w}$ Toruniu przez wielkiego mistrza krzyżackiego Teodoryka von Altenburga i następnie potwierdzenie tego prawa przez jego następcę, Ludwika Königa, w roku 1345 (Cicha 2010, s. 142). Kolejnym źródłem świadczącym o czasie trwania budowy jest dokument dotyczący fundacji kaplicy św. Zofii, dokonanej przez braci Jana Altewiese i Jana Jungewiese w 1349 r.

Dokładniejsze określenie momentu pojawienia się cysterek w Toruniu i przy kościele św. Jakuba również napotyka trudności. Zgodnie z ustaleniami, jakich dokonał XIX-wieczny historyk Jakub Fankidejski, za datę ich przybycia przyjęło się uznawać rok 1263, czego źródłem stały się adnotacje Erazma Rümplera, sekretarza miasta Torunia z 1598 r. (Sulkowska-Tuszyńska, Cicha 2010, s. 252). Nie wiadomo natomiast, gdzie znajdowało się pierwsze miejsce zamieszkania zakonnic. Potwierdzeniem hipotezy o ich przebywaniu w sąsiedztwie kościoła są wyniki badań archeologiczno-architektonicznych prowadzonych na tym terenie (Sulkowska-Tuszyńska, Cicha 2010, s. 253).

Świątynia poniosła znaczne straty podczas oblężenia krzyżackiego w 1455 r., kiedy spłonęła prawie połowa Nowego Miasta wraz z wieżą kościoła i dzwonami. W tym czasie funkcjonowały przy kościele szkoła parafialna i dwa szpitale: jeden przy ulicy Szpitalnej, którego budynek zachował się do czasów współczesnych, oraz Szpital św. Piotra i Pawła, położony przy Wielkich Garbarach (Krantz-Domasłowska, Domasłowski 2001, s. 14).

W drugiej połowie XVI w. rozpoczęła się nowa karta w dziejach kościoła św. Jakuba, związana z tzw. okresem protestanckim. Zapoczątkowana wystąpieniem Marcina Lutra w 1517 r. reformacja znalazła swoich zwolenników także w Toruniu, w którym przewaga ludno- 
ści niemieckojęzycznej systematycznie wzrastała w XVI stuleciu. Spowodowało to stopniową dominację protestantów w Radzie Miejskiej, którzy sukcesywnie przejmowali na własność kościoły katolickie. Fali dominacji protestanckiej nie zdołał się również oprzeć kościół św. Jakuba, który od roku 1557 przez 110 lat pełnił funkcję fary luterańskiej. W okresie reformacji nastąpiła znacząca zmiana w wystroju świątyni rozebrane zostały średniowieczne ołtarze boczne, usunięto relikwie i puszki z mens ołtarzowych oraz relikwiarzy, zniknęły także figury świętych i wszystko, co wiązało się z ich kultem (Birecki 2010, s. 248). Świadectwem dawnych czasów pozostały jedynie gotyckie malowidła ścienne, które protestanci postanowili zachować. Z czasem, kiedy zaniedbywany przez gospodarzy ołtarz główny uległ destrukcji, wymieniono go na nowy. Jego ślady można odkryć wyłącznie dzięki badaniom archeologicznym. Ponadstuletnia obecność ewangelików w kościele św. Jakuba miała znaczący wpływ na wnętrze świątyni - pojawiły się m.in. ławy dla patrycjatu, siedziska, nowa chrzcielnica, organy, kazalnica i epitafia luterańskich kaznodziejów (Birecki 2010, s. 248253). Wraz z przejęciem kościoła przez ewangelików zajęte zostały również budynki klasztorne, co doprowadziło do kryzysu w dziejach zgromadzenia, zażegnanego dopiero po odzyskaniu przez katolików kościoła i budynków klasztornych w 2. połowie XVII w.

Zarówno w katolickim, jak i protestanckim okresie użytkowania kościoła wnętrze świątyni oraz jej otoczenie były przestrzenią grzebalną (Sulkowska-Tuszyńska, Górzyńska 2010, s. 41). Mimo że dotychczas nie przeprowadzono badań archeologicznych wewnątrz budowli, z całą pewnością dokonywano $\mathrm{w}$ niej pochówków, o czym świadczą liczne płyty nagrobne i epitafia, a także analogie wobec innych kościołów z tego okresu. Nie ma natomiast żadnych wątpliwości co do faktu funkcjonowania przykościelnego cmentarza w okresie najpóźniej od XIV do XIX w. Potwierdzają to przeprowadzone w latach 2008-2015 badania archeologiczno-architektoniczne, podczas których odkrywano duże ilości nagromadzonych szkieletów ludzkich, często zachowanych w całości w układzie rzędowym, nawiązującym do osi kościoła. Innym dowodem świadczącym o istnieniu na tym terenie cmentarza są dwa niewielkie budynki, wykonane w stylu gotyckim. Pierwszy, zwany ossuarium bądź kostnicą, wkomponowany w linię murów od strony Rynku No- 
womiejskiego, służył do przechowywania kości, usuwanych co pewien czas z kwater cmentarza w celu uzyskania miejsca na nowe pochówki. Natomiast drugi budynek, przylegający do bryły kościoła, nazywany kaplicą ogrójcową, służył rozważaniom Męki Pańskiej (SulkowskaTuszyńska, Górzyńska 2010, s. 41). Główne wejście na dawny cmentarz przykościelny prowadziło przez ozdobną bramę, usytuowaną w północno-zachodnim narożniku murów.

Kolejny, burzliwy okres w dziejach kościoła i parafii rozpoczął się w drugiej połowie XVII w., podczas potopu szwedzkiego. Narastające antyprotestanckie nastroje sprzyjały staraniom zakonu o odzyskanie swojej dawnej własności, choć nie było to sprawą łatwą. Decyzje podejmowano wówczas na sejmikach, co przedłużało ich rozstrzygnięcie. Orzeczenie $\mathrm{w}$ tej sprawie $\mathrm{z}$ roku 1661, ostatecznie pomyślne dla katolików, odraczano z powodu protestów mieszczan obwinianych przez mniszki o zniszczenie klasztoru. Ponadto wyrok naruszał warunki zawartego wcześniej ze Szwecją pokoju oliwskiego (1660 r.), potwierdzającego prawa religijne i polityczne miast obowiązujące w nich przed wojną. Pomimo tych trudności oraz innych wydarzeń, jak np. gróźb wysadzenia kościoła przez mieszczan czy też uderzenia pioruna w jego wieżę, co odebrano jako przejaw gniewu Bożego, w 1667 r. zakonnice w asyście wojsk królewskich oraz prywatnych oddziałów starosty inowrocławskiego Pawła Ludwika Szczawińskiego powróciły do swojej dawnej świątyni, szkoły i szpitala (Krantz-Domasłowska, Domasłowski 2001, s. 18). Po odzyskaniu terenu nastąpiła rozbudowa klasztoru. W pierwszej kolejności połączono budynek konwentu z kościołem, pośpiesznie budując tzw. łącznik, przebadany przez archeologów w roku $2013^{3}$.

Po II rozbiorze Polski w 1793 r. Toruń znalazł się w granicach Prus, co miało niekorzystny wpływ na życie parafii, podobnie jak późniejsze wojny napoleońskie. Zaszła konieczność sprzedaży niektórych dóbr kościelnych, takich jak wota, świeczniki i inne elementy wystroju. Na podstawie inwentarza z $1817 \mathrm{r}$. wiadomo, że w kościele znajdowało się

\footnotetext{
${ }^{3}$ Odkryto wówczas oba fundamenty łącznika i jego posadzkę na długości kilku metrów. W poprzednich latach odsłaniano mniejsze fragmenty ścian.
} 
wówczas 17 ołtarzy $^{4}$ (Krantz-Domasłowska, Domasłowski 2001, s. 21). Coraz większe ograniczenia wobec zakonu i jego kasata w 1833 r. zakończyły okres obecności mniszek przy kościele ${ }^{5}$. Wydarzenie to nie pozostało bez konsekwencji dla budynków klasztornych. Wkrótce część z nich, wraz z tzw. łącznikiem, została wyburzona, a te, które się zachowały, przejęło wojsko pruskie. Do obecnych czasów przetrwała jedynie prostokątna budowla, umiejscowiona po południowej stronie kościoła, będąca najstarszą zachowaną częścią dawnego kompleksu klasztornego (ul. św. Jakuba 20 a) (ryc. 2).

W 2. połowie XIX w. przeprowadzono pierwsze prace konserwatorskie w kościele św. Jakuba, których inicjatorem był zachwycony budowlą architekt Ferdynand von Quast. W późniejszym czasie nadzór nad pracami sprawował wybitny znawca architektury krzyżackiej Konrad Steinbrecht. Na początku XX w. naprawiono okna, schody w wieży, posadzki oraz sklepienia po południowej stronie świątyni. W planach było także odsłonięcie łuków oporowych przez obniżenie połaci dachów w nawach głównych. Po odzyskaniu niepodległości przez Polskę w 1918 r. budynki poklasztorne zostały zajęte przez Wojsko Polskie. Według zapisów z 1922 r. zagospodarowano je na biura 4. Inspekcji Twierdzy i Sądu 35. Dywizji z aresztem (Sulkowska-Tuszyńska, Cicha 2010, s. 255). W okresie międzywojennym działały przy kościele różnego rodzaju organizacje katolickie, jak schronisko św. Jakuba dla ubogich starców, parafialne przedszkole Dzieciątka Jezus oraz liczne bractwa modlitewne, m.in. Bractwo Najświętszego Serca Pana Jezusa czy Bractwo Szkaplerzne, istniejące do dziś.

\footnotetext{
${ }^{4}$ Poza ołtarzem głównym były to ołtarze: św. Wawrzyńca, Opatrzności Bożej, Matki Boskiej Szkaplerznej, św. Józefa, św. Antoniego, św. Stanisława, św. Rocha, św. Piotra, św. Krzyża, św. Anny, św. Walentego, św. Michała Archanioła, św. Barbary, Matki Boskiej Pocieszenia, św. Benedykta i św. Scholastyka (Krantz-Domasłowska, Domasłowski 2001, s. 21).

${ }^{5} 11$ z nich w 1833 r. zmuszonych było opuścić klasztor i przenieść się do Żarnowca, gdzie Prusacy utworzyli rodzaj zbiorczego domu dla wszystkich likwidowanych zgromadzeń żeńskich z obszaru zaboru pruskiego. W 1866 r. zmarła w Żarnowcu Zofia Winnicka, ostatnia z toruńskich benedyktynek (Krantz-Domasłowska, Domasłowski 2001, s. 21-22).
} 


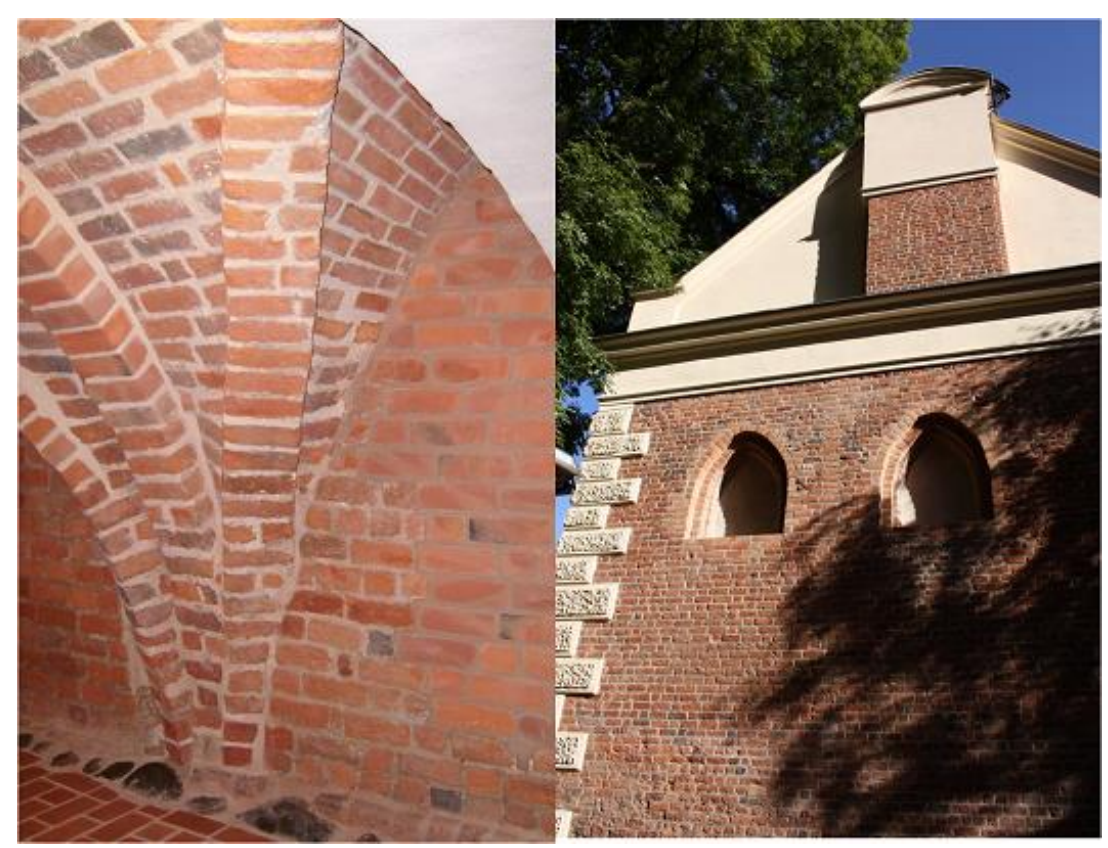

Ryc. 2. Budynek dawnego klasztoru - gurty sklepienia w piwnicy oraz elewacja północna z częściowo zrekonstruowanymi po remoncie gotyckimi arkadami (fot. A. Cicha)

Opisując historię kościoła Jakubowego nie można pominąć osób, które się dla niego zasłużyły, jak ks. Stanisław Pełka (proboszcz w latach 1918-1928), jego następca ks. kanonik Leon Kozłowski, ks. wikariusz Teofil Falkowski, który poniósł męczeńską śmierć w niemieckim obozie w Dachau w 1942 r. oraz ks. Aleksander Rutecki, któremu udało się ocaleć z tego miejsca kaźni. W krypcie pod prezbiterium pochowano biskupa łuckiego Adolfa Piotra Szelążka, założyciela Zgromadzenia Sióstr św. Teresy od Dzieciątka Jezus, którego proces beatyfikacyjny, rozpoczęty w 2013 r., trwa nadal.

W swojej najnowszej, powojennej historii kościół św. Jakuba przechodził kilkakrotnie prace renowacyjne, przede wszystkim w zakresie konserwacji gotyckich malowideł ściennych, wykonywanych w latach 
pięćdziesiątych i dziewięćdziesiątych XX w. W celu lepszego zabezpieczenia i udostępnienia cennych zabytków, w latach osiemdziesiątych XX w. przekazano niektóre spośród nich w depozyt do Muzeum Diecezjalnego w Pelplinie, gdzie można je podziwiać do dziś. Przez ostatnie dwie dekady kontynuowano prace restauratorskie kościoła, obejmujące jego mury zewnętrzne i wewnętrzne. $Z$ kolei w 2008 r. władze miasta postanowiły przekazać zaniedbany budynek po dawnym klasztorze ${ }^{6}$ Muzeum Okręgowemu w Toruniu, wskutek czego koniecznością stało się przeprowadzenie niezbędnego remontu, połączonego $\mathrm{z}$ nadzorem archeologicznym. Jego przebieg został opisany w obszernym artykule Krystyny Sulkowskiej-Tuszyńskiej i Anny Cichej, wydanym w 2010 r. (Sulkowska-Tuszyńska, Cicha 2010, s. 255-273). Należy dodać, że jeszcze przed podjęciem prac wykopaliskowych doszło do rozpoznania architektonicznego budynku, na podstawie którego potwierdzono średniowieczne pochodzenie budowli. Świadczą o tym znajdujące się $\mathrm{w}$ piwnicach gotyckie sklepienia krzyżowe oraz inne elementy architektury z tego okresu, widoczne w murach przyziemia, piętra i partiach szczytowych (Sulkowska-Tuszyńska, Cicha 2010, s. 255). W chwili obecnej w budynku tym mieszczą się biura muzealne oraz magazyny działu archeologii i biblioteka Muzeum Okręgowego w Toruniu.

\section{Wyróżnione zespoły nawarstwień oraz ich chronologia}

Łącząc wiadomości pochodzące z opracowań źródeł historycznych na temat kościoła św. Jakuba i związanego $z$ nim klasztoru benedyktynek, a zarazem konfrontując je $\mathrm{z}$ wiedzą pochodzącą $\mathrm{z}$ badań archeologicznych można podjąć próbę powiązania przeanalizowanych nawarstwień z konkretnymi okresami w dziejach świątyni i otaczających ją obiektów, a tym samym określenia ich chronologii. Przedstawiona w artykule analiza dotyczy odkryć, jakich dokonano w sześciu wykopach założonych po południowej stronie kościoła św. Jakuba w latach 2008-2015 (ryc. 3). Są to wykopy: W-4/10, W-5/10, W-8/11, W-12/13, $\mathrm{W}-14 / 13 \mathrm{i} \mathrm{W}-16 / 15^{7}$. Założenie każdego z nich służyło konkretnym ce-

\footnotetext{
${ }^{6} \mathrm{~W}$ okresie powojennym pełnił on funkcje mieszkaniowe.

${ }^{7}$ Profile północne wykopów znajdują się na rycinach 4-7. Objaśnienia zastosowanych symboli zob. ryc. 7
} 


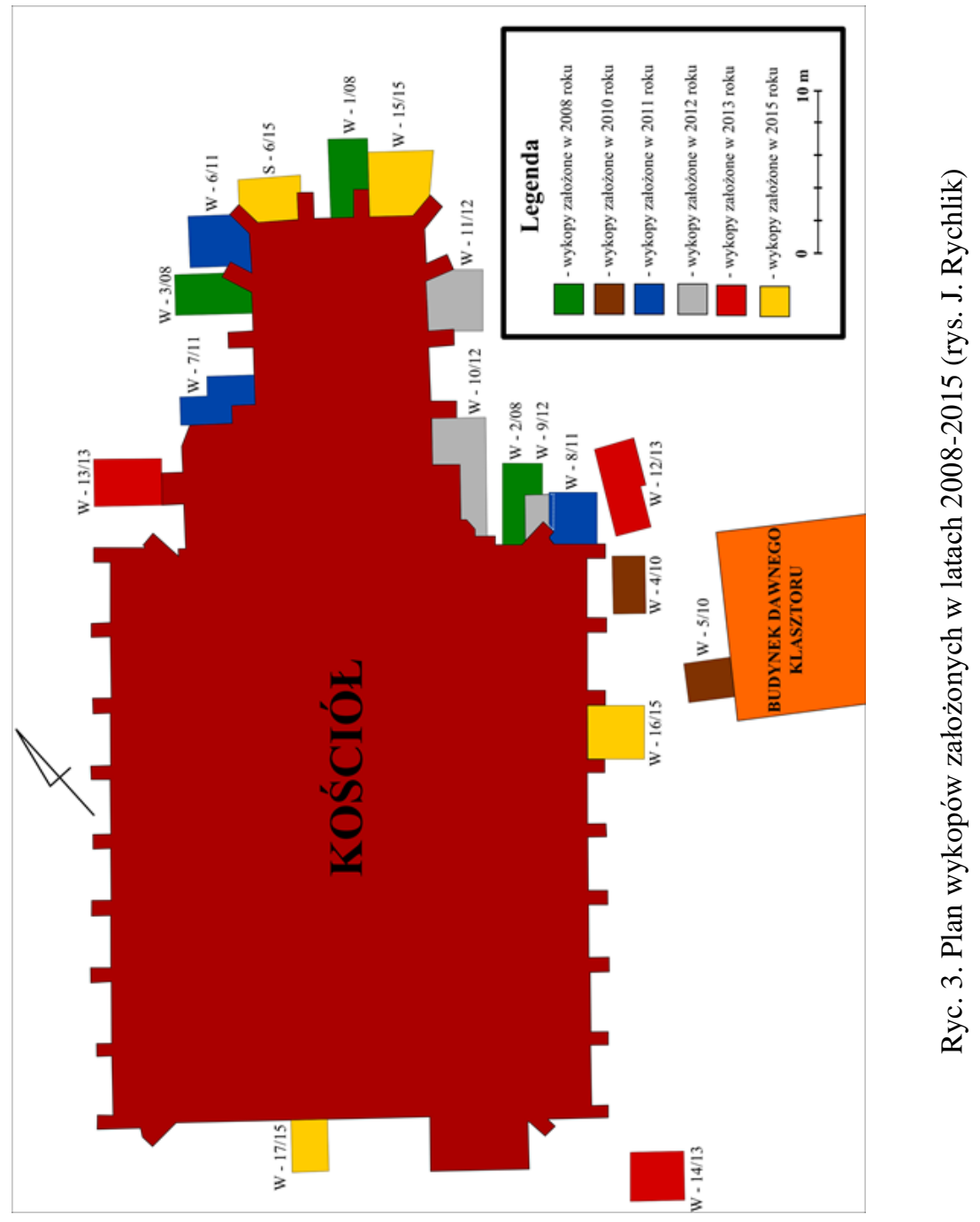


lom naukowym, dotyczącym różnych aspektów działalności prowadzonej wokół kościoła.

Opisane nawarstwienia grupują się w kilka zespołów, związanych z określonymi obszarami wokół kościoła, powstającymi w różnych odcinkach czasowych. Wśród nich można wymienić cmentarz przykościelny, kaplice boczne wzdłuż nawy południowej i tzw. łącznik klasztorny. W obrębie każdego obszaru (obiektu) wyróżniono zespoły stratyfikacyjne, w skład których wchodziły poszczególne warstwy mechaniczne. Wszystkie zespoły mają chronologię, określoną w sposób szczegółowy lub ogólny na podstawie analizy przedstawionych nawarstwień i wyników badań.

\section{Cmentarz przykościelny}

Otaczający kościół św. Jakuba cmentarz jest jedną z wielu nekropolii, jakie funkcjonowały od średniowiecza do przełomu XVIII i 1. połowy XIX w. przy chrześcijańskich świątyniach. W wyniku badań archeologicznych stwierdzono, że całą przestrzeń przykościelną wypełniały liczne pochówki, składane tu od początku istnienia kościoła, a więc najpóźniej od początku XIV w. ${ }^{8}$ Jednakże w różnych częściach obszaru otaczającego nowomiejską świątynię okres oraz intensywność użytkowania cmentarza były zróżnicowane. W pobliżu prezbiterium najintensywniej użytkowane warstwy grobowe pochodzą z XV w. (Sulkowska-Tuszyńska, Górzyńska 2010, s. 44). Ciała niektórych zmarłych składano wówczas w pozycji bocznej, a dzieci chowano u stóp osób dorosłych. Popularność tego miejsca w prosty sposób można wytłumaczyć chęcią bycia pochowanym jak najbliżej Najświętszego Sakramentu oraz

\footnotetext{
${ }^{8}$ Obecnie trwają badania nad datowaniem cegły i zapraw z fundamentów, dlatego na potrzeby niniejszego opracowania przyjmujemy najpóźniejszy czas dla początku nekropolii, czyli położenie kamienia węgielnego pod budowę prezbiterium II (1309). Wyraźnie widoczne zmiany w fundamentach prezbiterium są mocną podstawą do twierdzenia, że przed 1309 r. na tych samych fundamentach było tzw. prezbiterium I. Najpewniej też był tu cmentarz w XIII w. Jednakże w pochówkach nie widać żadnej różnicy - brakuje wyposażenia i podstaw do datowania. Istnieje pewność co do tego, że żaden z grobów nie został przecięty przez fundament prezbiterium. Być może analiza ceramiki z najstarszych warstw cmentarza pomoże w dokonaniu takiego rozgraniczenia.
} 
ołtarza, w którym znajdowały się relikwie świętych. Wydaje się oczywiste, że w strefie tej chowano bogatszych toruńskich mieszczan'. Tereny przy północnej i zachodniej ścianie również stanowiły cmentarz. Ich użytkowanie rozpoczęło się najpóźniej w XIV w., choć w niektórych miejscach pochówki mogły być wykonywane w wieku XIII, o czym świadczą znaleziska ceramiki datowanej na ten okres, odkryte w najniższych warstwach (Sulkowska-Tuszyńska, Górzyńska 2010, s. 44). W przypadku interesującego nas obszaru, znajdującego się pomiędzy południową ścianą kościoła a nieistniejącą obecnie w całości zabudową klasztorną ${ }^{10}$, na podstawie badań w latach 2010 i 2013 podjęto próbę ustalenia, jaki mógł być charakter tej części cmentarza. Dzięki temu stwierdzono, że gęstość zapełnienia kwater przy południowej ścianie kościoła była znacznie mniejsza od tej, która wystąpiła wokół prezbiterium.

Po południowej stronie kościoła założono dwa wykopy, których głównym celem było poznanie nawarstwień związanych z cmentarzem istniejącym tu od początku XIV (lub nieco wcześniej) do końca XVIII w. - wykop W-4/10 (ryc. 3, ryc. 4) z 2010 r. i W-14/13 (ryc. 3, ryc. 5) z 2013 r. Wydzielono trzy zespoły warstw, istniejące w trzech następujących po sobie odcinkach czasowych. W skład pierwszego z nich wchodzą najniżej położone poziomy cmentarza, których użytkowanie przypada na okres między przełomem XIII i XIV w. a przełomem XV i XVI w. Najgłębiej leżący ślad pochówków po południowej stronie kościoła zachował się w postaci grobu G-57/15 z wykopu W-16/15 (ryc. 3, ryc. 6), znajdującego się na wysokości 48,34 m n.p.m., czyli 3,22 metra od dzisiejszego poziomu gruntu. Jednak w wyniku porównania głębokości położenia najniższych pochówków we wszystkich wykopach okazało się, że jest ona podobna i wynosi około 3 metrów od współczesnej warstwy użytkowej. Jedynie w przypadku dwóch wykopów, związanych z tzw. łącznikiem klasztornym, była ona mniejsza ${ }^{11}$.

\footnotetext{
${ }^{9}$ Dowodami na to są bogate znaleziska $\mathrm{z}$ warstw grobowych przy prezbiterium, np. srebrna brosza z okresu XVII-XVIII w. (Sulkowska-Tuszyńska, Górzyńska 2010, s. 44).

${ }^{10}$ Została ona w większości rozebrana po 1833 r., po kasacie zakonu benedyktynek (Sulkowska-Tuszyńska, Cicha 2010, s. 255).

${ }^{11} \mathrm{~W}$ poszczególnych wykopach głębokość ta wynosiła: 3,22 $\mathrm{m}(\mathrm{W}-16 / 15), 3,08 \mathrm{~m}$ (W-5/10), 3 m (W-14/13), 2,97 m (W-4/10), 2,58 m (W-8/11), 2,04 m (W-12/13); nieco większe zróżnicowanie dotyczyło miąższości średniowiecznych poziomów cmentarza, która wahała się od 1,45 m w wykopie W-16/15 do 0,25 m w wykopie W-12/13.
} 


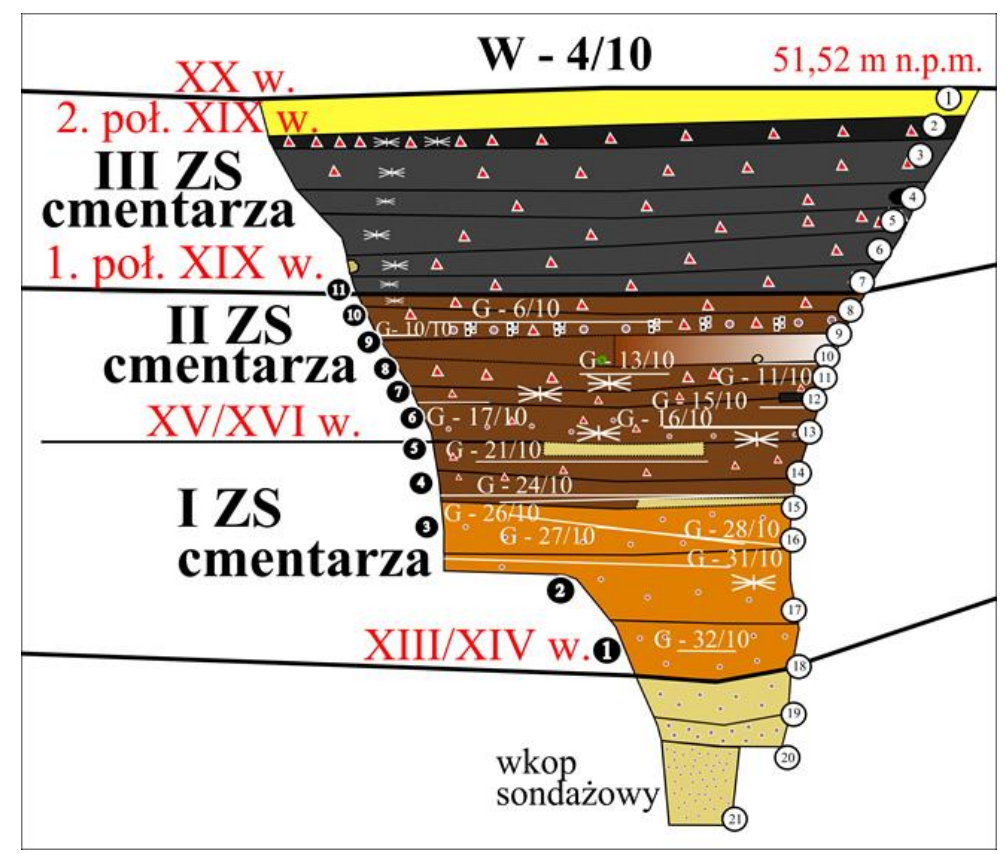

Ryc. 4. Profil północny wykopu W-4/10 (legenda zob. ryc. 7) (rys. J. Rychlik)

Wartości najbardziej do siebie zbliżone wystąpiły w czterech wykopach (W-16/15, W-5/10, W-14/13, W-4/10), w których pochówki znajdowały się na podobnej głębokości. Ogółem w I zespole nawarstwień wyodrębniono 9 poziomów grobów - od najgłębszych do najwyżej wkopanych w okresie bliskim przełomu średniowiecza i nowożytności.

Pierwszy poziom grobów zawierał rdzawy, rdzawożółty lub rdzawobrązowy piasek, przeplamiony z żółtą gliną i piaskiem, przemieszany z otoczakami średniej i dużej wielkości oraz z występującymi w niektórych miejscach węglami drzewnymi. Najgłębiej umieszczony pochówek (grób G-57/15), złożony pod arkadą ściany kościoła, odkryto w wykopie $\mathrm{W}-16 / 15^{12}$. W niektórych wykopach zarejestrowano również przemieszane szczątki kostne (wykopy: W-14/13, W-5/10, W-8/11).

\footnotetext{
${ }^{12}$ Niwelacja: 48,48-48,40 m n.p.m., 48,26-48,20 m n.p.m. (Inwentarz warstw i niwelacji wykopu W-16/15, 1.p. 22).
} 


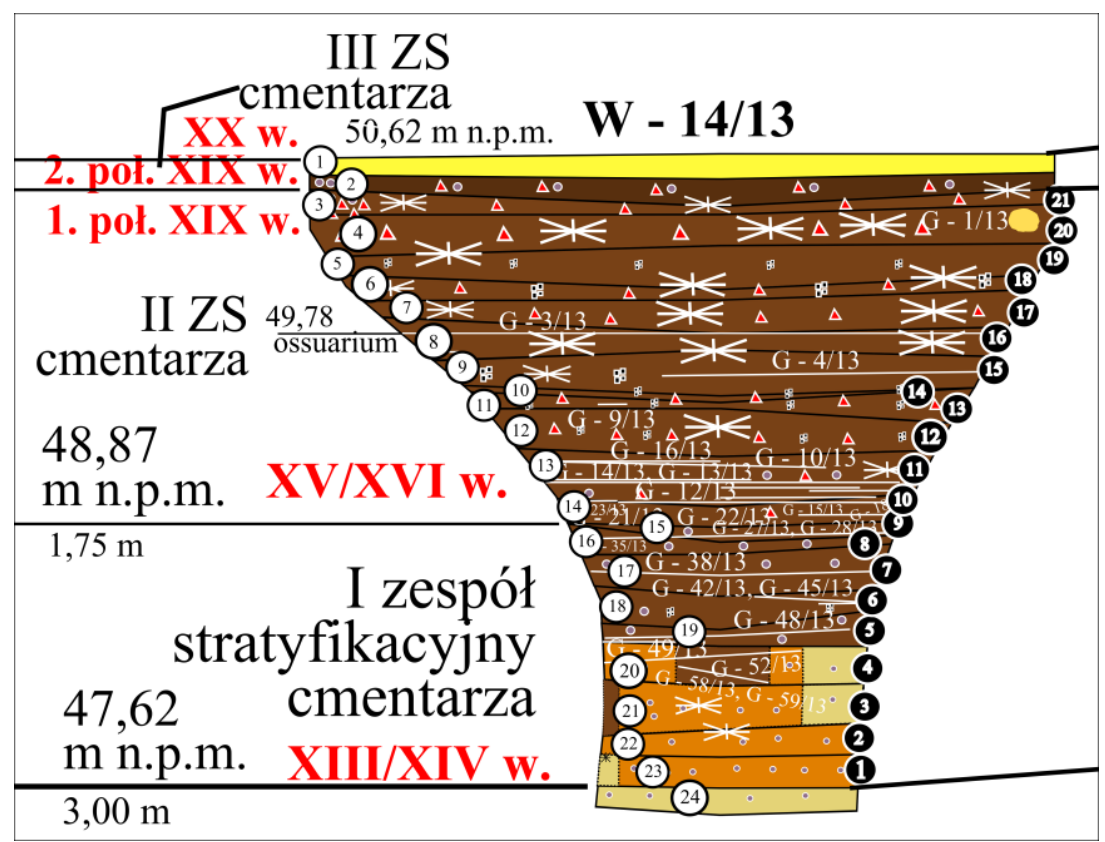

Ryc. 5. Profil północny wykopu W-14/13 (legenda zob. ryc. 7) (rys. J. Rychlik)

Zachowane w układzie anatomicznym szczątki kostne odsłonięto w 2. poziomie grobowym w wykopach: W-16/15, W-4/10, W-8/11 (ryc. 3) i W-12/13 (ryc. 3, ryc. 7). Stanowiło je 8 grobów ${ }^{13}$. Na wysokości drugiego poziomu pochówków w wykopach W-5/10 (ryc. 3, ryc. 6) i W-14/13 uchwycono jedynie luźne, przemieszane wtórnie kości. Otoczenie tych znalezisk stanowił na przeważającym obszarze rdzawy piasek z jaśniejszymi przebarwieniami, nie wystąpił on jedynie w wykopach związanych z odkryciem tzw. łącznika klasztornego (W-8/11, $\mathrm{W}-12 / 13)$, w których zalegała szarobrunatna, spiaszczona próchnica. W tych miejscach dominowała szarobrunatna, spiaszczona próchnica $\mathrm{z}$ drobinami ceglanego gruzu i zaprawy.

\footnotetext{
${ }^{13}$ Groby: G-56/15, G-52/15, G-31/10, G-53/11, G-54/11, G-51/13, G-56/13 i G-57/13.
} 


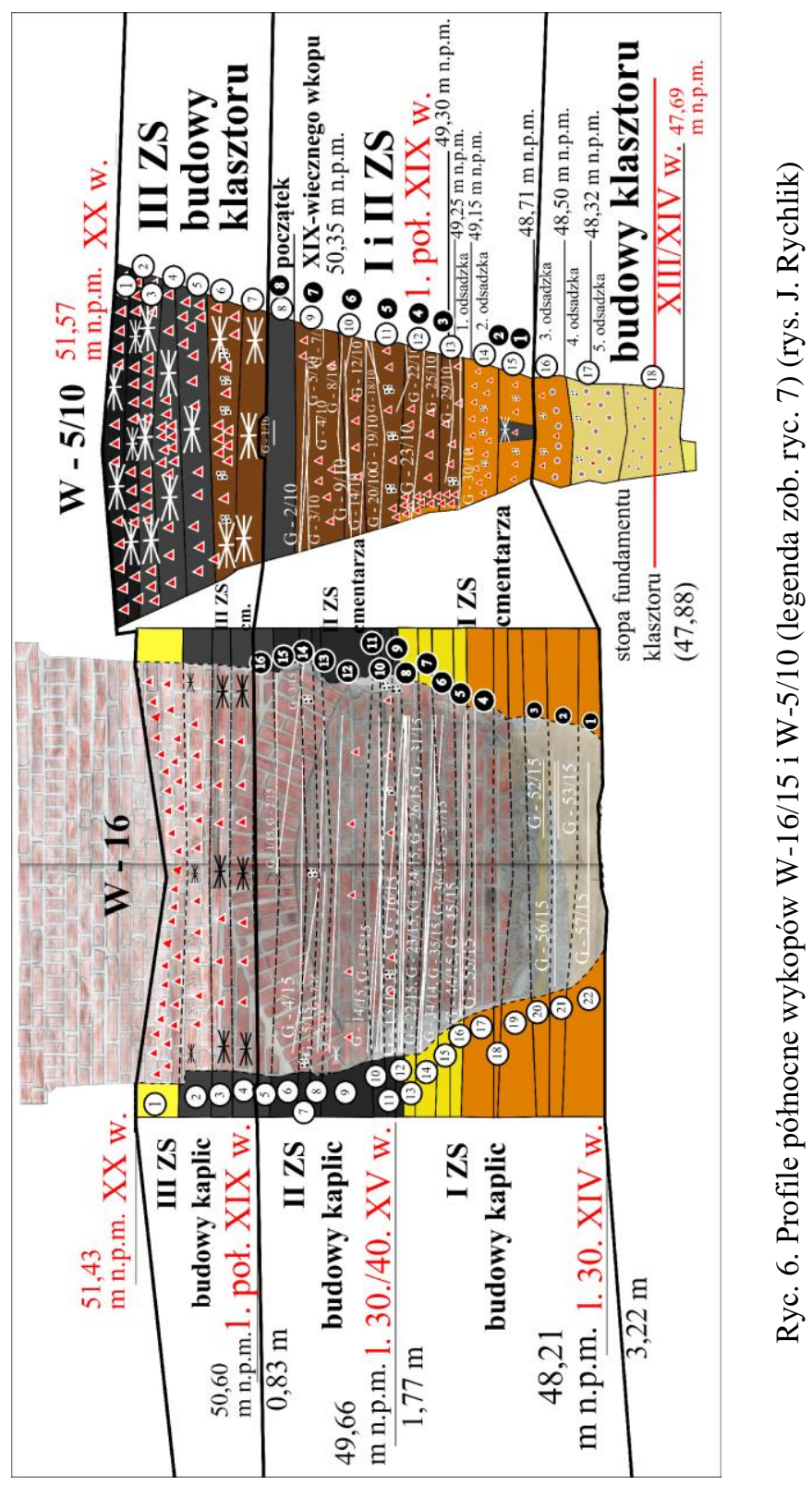




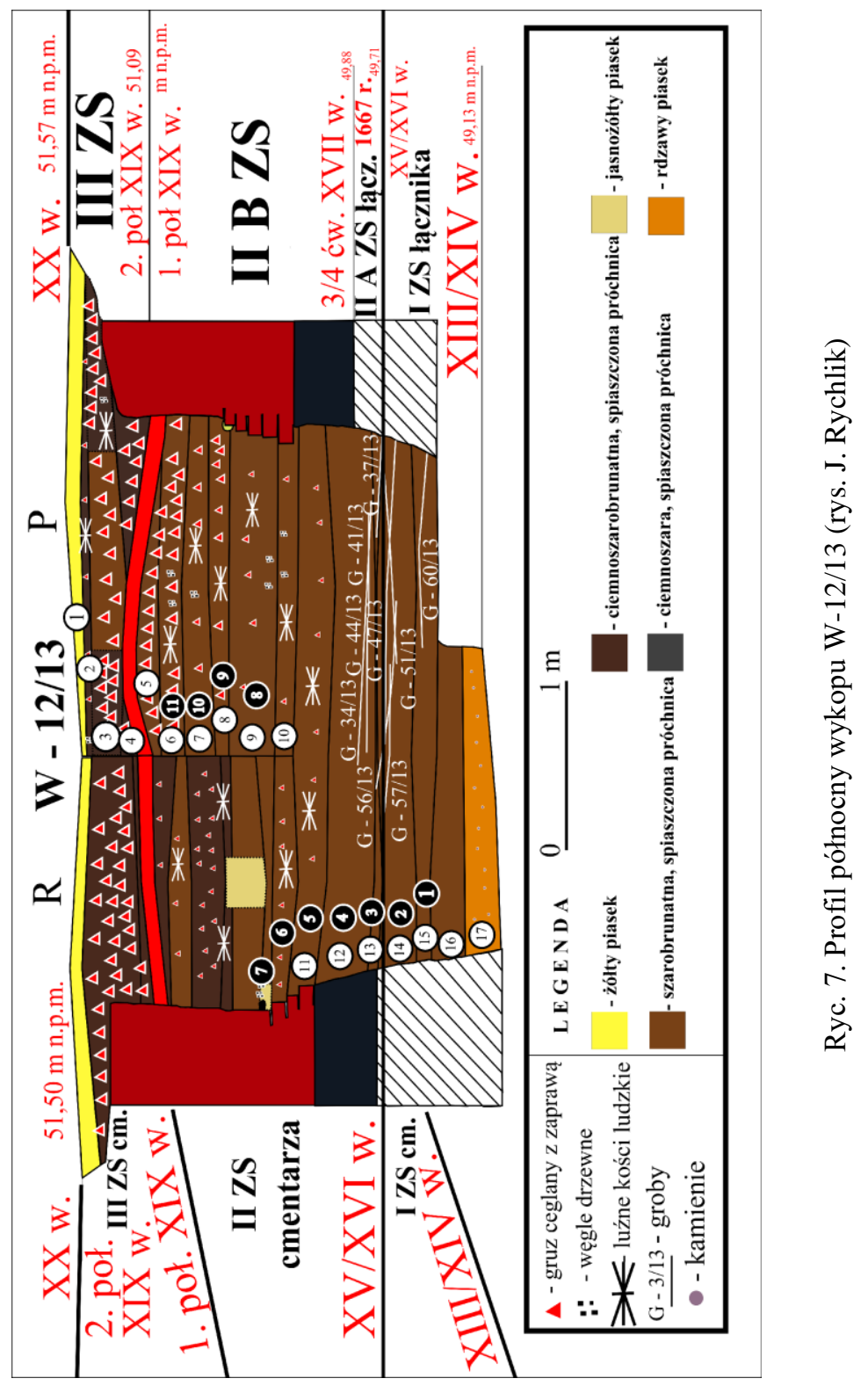


Na wysokości 3. poziomu grobowego znajdowało się 9 nienaruszonych pochówków ${ }^{14}$, które odkryto w czterech wykopach ${ }^{15}$. Dwa pozostałe (W-16/15 i W-5/10) zawierały jedynie przemieszane wtórnie kości. W przypadku wykopu W-16/15 między poziomami 2. i 3. nastąpiła przerwa w postaci trzech warstw mechanicznych (18., 19. i 20. WM), w których nie były obecne jakiekolwiek szczątki kostne. Barwa i skład warstw nie odbiegały znacząco od opisanych powyżej jednostek, zawierających głównie rdzawy, gruboziarnisty piasek z przeplamieniami szarobrunatnej, spiaszczonej próchnicy.

Od wysokości 4. poziomu grobowego charakter nawarstwień uległ zmianie we wszystkich badanych wykopach. Stanowily one szarobrunatną, spiaszczoną próchnicę, przemieszaną gdzieniegdzie $\mathrm{z}$ fragmentami gruzu ceglanego, zaprawy, spieków szklanych i drobnych węgli drzewnych. W ich obrębie wystąpiło 8 grobów, które obecne były we wszystkich wykopach oprócz wykopu W-12/13, w którym warstwy związane ze średniowiecznym cmentarzem kończą się na 3. poziomie grobowym $^{16}$.

Kolejny, 5. poziom stanowi warstwa szarobrunatnej, spiaszczonej próchnicy z gruzem ceglanym, drobinami zaprawy i pojedynczymi wtrętami rdzawego piasku, fragmentami węgli drzewnych i kamieniami. Na tej wysokości wystąpiło mniej grobów niż w przypadku poprzedniego poziomu. Zalegały one $\mathrm{w}$ trzech wykopach i miały następujące numery: G-25/10 i G-29/10 (W-5/10), G-48/13 i G-49/13 (W-14/13), G-21/10 (W-4/10). W przypadku wykopu W-16/15 zachowały się jedynie luźne kości, które były obecne także w pozostałych wykopach obok nienaruszonych pochówków. Z kolei w wykopie W-4/10 warstwy średniowiecznego cmentarza zakończyły się na poziomie 5 .

Jednostką, która wśród warstw średniowiecznego cmentarza szczególnie obfitowała $\mathrm{w}$ pochówki, był 6 . poziom grobowy ${ }^{17}$, zawierający

\footnotetext{
${ }^{14}$ Groby: G-58/13, G-59/13, G-27/10, G-28/10, G-50/11, G-52/11, G-51/13, G-56/13, G-57/13.

${ }^{15} \mathrm{~W}-14 / 13, \mathrm{~W}-4 / 10, \mathrm{~W}-8 / 11, \mathrm{~W}-12 / 13$.

${ }^{16} \mathrm{Z}$ kolei na wysokości 4 . poziomu grobowego w wykopie W-8/11 kończą się pochówki związane ze średniowiecznym cmentarzem.

${ }^{17}$ Charakter warstw nie odbiegał znacząco od poprzednio opisanych; w wykopie W-16/15 wystąpiła większa ilość węgli drzewnych.
} 
łącznie 8 szkieletów. Najwięcej wystąpiło ich w wykopie W-16/15 (G34/15, G-35/15, G-36/15, G-37/15), w którym pojawiały się również ślady trumien lub mar, co może oznaczać, że chronologia tej warstwy jest zbliżona do XV w., gdy zmarłych zaczęto składać do trumien (Sulkowska-Tuszyńska, Górzyńska 2010, s. 45). Mniej grobów było w wykopach W-5/10 (G-22/10, G-23/10) i W-14/13 (G-42/13, G-45/13). Na tej wysokości kończą się groby związane ze średniowiecznym cmentarzem w wykopie W-5/10.

Poziom grobowy o numerze 7., składający się z szarobrunatnej, spiaszczonej próchnicy, miały wykopy W-16/15 i W-14/13, w których zarejestrowano łącznie trzy groby. Dwa $\mathrm{z}$ nich leżały $\mathrm{w}$ pierwszym z wymienionych wykopów (G-26/15, G-31/15), w drugim natomiast zalegał grób G-38/13.

Dalszy, 8. poziom, w którym charakter nawarstwień nie uległ zmianie w stosunku do opisanego powyżej, zawierał trzy groby w wykopie W-6/15 (G-22/15, G-23/15, G-24/15) i jeden w wykopie W-14/13 (G$35 / 13)$.

Ostatnie groby, prawdopodobnie związane $\mathrm{z}$ istnieniem średniowiecznego cmentarza $\mathrm{z}$ okresu XIII/XIV-XV/XVI w., to położone $\mathrm{w}$ wykopie W-14/13 pochówki o numerach G-27/13 i G-28/13, zalegające w 9. poziomie grobowym, który obejmował jedynie warstwy $\mathrm{z}$ tego wykopu $^{18}$. Zachowanym w układzie anatomicznym szkieletom towarzyszyły luźne kości, które znajdowały się w warstwie szarobrunatnej, spiaszczonej próchnicy przemieszanej z gliną, piaskiem i otoczakami.

Najwięcej, czyli 16 pochówków związanych z okresem XIII/XIV w. - XV/XVI w. zalegało w wykopie W-16/15. Mniejsze ich ilości wyeksplorowano w kolejnych wykopach, w których grobów z początkowego okresu funkcjonowania cmentarza było: 11 (W-14/13), 7 (W4/10), 7 (W-8/11), 5 (W-5/10) i 3 (W-12/13). Łącznie we wszystkich wykopach odkryto 49 średniowiecznych pochówków oraz liczne, wtórnie przemieszane kości. Praktycznie jedyną kategorią znalezisk towarzyszących warstwom średniowiecznego cmentarza, pozwalających je powiązać z tym odcinkiem czasowym, są fragmenty ceramiki

\footnotetext{
${ }^{18}$ Niwelacja: 48,94-48,85 m n.p.m., 48,84-48,78 m n.p.m. (Inwentarz warstw i niwelacji wykopu W-14/13, 1.p. 15.).
} 
siwej. Poza nią odnajdywano przedmioty metalowe (głównie gwoździe), które nie mogą służyć jako dobry wyznacznik chronologiczny. Górną granicę I zespołu warstw wskazuje pojawienie się większej ilości przedmiotów charakterystycznych dla okresu nowożytnego (wśród nich największe znaczenie mają wianki grobowe). Reasumując, po południowej stronie kościoła prawdopodobnie najwcześniej zaczęto grzebać zmarłych zaraz po zakończeniu budowy nawy południowej (XIV w.), ale na długo przed budową kaplicy św. Walentego (XV w.). W ostatniej, zachodniej kwaterze jeszcze nie istniał cmentarz, we wschodniej (W-8/11, W-12/13) zaczęto grzebać po zakończeniu któregoś z etapów budowy prezbiterium II lub nowożytnego łącznika klasztornego. Gdy zaczęto grzebać w kwaterze zachodniej (W-14/13), grzebano też wzdłuż nawy południowej $(\mathrm{W}-16 / 15, \mathrm{~W}-4 / 10, \mathrm{~W}-5 / 10)$ i na linii łącznika (W8/11, W-12/13). Na czas budowy kaplicy św. Walentego (W-16/15) zaprzestano w tym miejscu pochówków, by po kilku lub kilkunastu latach, po zakończeniu prac budowlanych (około 1430 r.), ponownie na całej długości kościoła chować zmarłych.

Drugi zespół nawarstwień cmentarza tworzą jednostki uformowane między przełomem XV i XVI w. a 1. połową XIX w., a więc czasem, w którym zaprzestano grzebania zmarłych wokół kościoła (SulkowskaTuszyńska, Górzyńska 2010, s. 41). Zespół ten stanowi nawarstwienia związane z użytkowaniem cmentarza w okresie nowożytnym. Jego podstawowym wyznacznikiem były występujące $\mathrm{w}$ warstwach zabytki, typowe dla omawianego odcinka czasowego. Należą do nich przede wszystkim tzw. wianki grobowe, które od około XV/XVI w. do końca XVIII w. wkładano zmarłym do grobów (Sulkowska-Tuszyńska, Górzyńska 2010, s. 45). Przedmioty tego typu były wyplatane z drucików (przeważnie brązowych, czasem srebrnych), nitek, gałązek ziela i kwiatów, a ich pozostałości znajdowane są najczęściej na czaszkach ${ }^{19}$, piersiach, biodrach, przy kolanach i stopach (Drążkowska 2006, s. 212213). Inne znaleziska związane $\mathrm{z}$ funkcjonowaniem nowożytnego cmentarza to m.in. dewocjonalia, które jednak w warstwach cmentarnych przy kościele św. Jakuba odnaleziono w bardzo małych iloś-

\footnotetext{
${ }^{19}$ Wówczas na czaszce pozostawało zielone, koliste przebarwienie. Bardzo wiele takich śladów odnaleziono także przy kościele św. Jakuba.
} 
$\operatorname{ciach}^{20}$. Kolejne kategorie zabytków wskazujące na nowożytną metrykę badanych warstw to liczne szpilki, którymi przypinano m.in. ozdoby do ubrań osób zmarłych ${ }^{21}$, monety, ćwieki służące do mocowania tkanin wewnątrz trumien, haftki, guziki oraz inne przedmioty osobiste znane z okresu nowożytnego. Wszystkie te zabytki odnajdywano w o wiele większych ilościach niż w przypadku nawarstwień cmentarza średniowiecznego. Jeszcze innym świadectwem określającym nowożytną chronologię opisywanych warstw są zachowane w kilku miejscach relikty trumien $^{22}$, widoczne w postaci ciemnych przebarwień.

Zaskakującą obserwację stanowi fakt, że niemal we wszystkich opisywanych wykopach wianki grobowe położone w najniższych poziomach zespołu cmentarza nowożytnego wystąpiły na tej samej głębokości, wynoszącej około $1,75 \mathrm{~m}$ od dzisiejszego poziomu gruntu. Jedynie w wykopie W-8/11 głębokość zalegania tych znalezisk była nieznacznie większa i wyniosła $1,90 \mathrm{~m}^{23}$. Pozwala to na określenie przybliżonej chronologii najniższych warstw II zespołu stratyfikacyjnego najwcześniej na przełom XV i XVI w., kiedy pojawił się zwyczaj składania wianków do grobów (Sulkowska-Tuszyńska, Górzyńska 2010, s. 45). Przedmioty te lub też ich relikty odnajdywane były w większości warstw składających się na opisywany zespół, co nie powinno dziwić, ponieważ wianki układano przy ciałach zmarłych co najmniej do XVIII w. (Sulkowska-Tuszyńska, Górzyńska 2010, s. 45). Z tego powodu wytwory te oraz wymienione wcześniej typy zabytków, które dość licznie wystąpiły w wyższych partiach cmentarza, stały się podstawą do określenia nowożytnej chronologii tej części nekropolii.

\footnotetext{
${ }^{20}$ Brak takich przedmiotów wskazuje na niewystępowanie na badanym cmentarzu zwyczajów znanych np. z Kujaw i Wielkopolski, polegających na wkładaniu do grobów różańców i innych dewocjonaliów (Sulkowska-Tuszyńska, Górzyńska 2010, s. 45). Być może wynikają one z silnych wpływów protestanckich.

${ }^{21}$ Do XVI/XVII w. rzadko grzebano zmarłych w odzieży (Sulkowska-Tuszyńska, Górzyńska 2010, s. 45).

${ }^{22}$ Od XV w. zmarłych zaczęto coraz częściej chować w trumnach (Sulkowska-Tuszyńska, Górzyńska 2010, s. 45).

${ }^{23}$ Głębokości zalegania wianków w pozostałych wykopach: 1,75 m (W-14/13), 1,77 m (W-16/15), 1,75 m (W-5/10), 1,77 m (W-4/10), 1,79 m (W-12/13).
} 
Najwięcej, tzn. 12 poziomów grobów ${ }^{24}$ odkryto w wykopie W-14/13. Skład każdego z nich był w zasadzie jednakowy i stanowił szarobrunatną, spiaszczoną próchnicę, przemieszaną w większości warstw z fragmentami gruzu ceglanego, drobinami zaprawy i otoczakami różnej wielkości, których więcej wydobywano w dolnych partiach nowożytnego cmentarza. Niektórym z warstw towarzyszyły drobiny węgli drzewnych, najczęściej wiązały się one z tymi jednostkami, w których odnajdywano duże ilości wtórnie przemieszanych kości ${ }^{25}$.

Zdecydowanie największe zagęszczenie pochówków zauważalne było w dwóch pierwszych poziomach grobowych wykopu W-14/13. Zalegało $\mathrm{w}$ nich łącznie $14 \mathrm{w}$ całości zachowanych szkieletów ${ }^{26}$ i pewna ilość luźnych kości. Na tej wysokości wystąpiły też najniżej położone wianki grobowe, które odkrywano w niemal każdej jednostce nowożytnego cmentarza. Od 12. do 21. poziomu grobowego w wykopie eksplorowano prawie wyłącznie luźne szczątki kostne, których szczególnie duże ilości obecne były w warstwach 8 . i 9. (16. i 15. poziom grobowy), od wysokości 49,78 m n.p.m. W związku z tym uznano, że poziomy te wyznaczają obszar ossuarium, utworzonego tu być może w XVIII w., gdy zaczynało brakować miejsca na nowe pochówki. $\mathrm{Z}$ tych warstw pochodzi wyjątkowe znalezisko binokli z zachowanym szkłem i etui z przełomu XVIII i XIX w. W poziomach 13.-20. odkryto zaledwie trzy nienaruszone groby (G-9/13, G-4/13, G-3/13, G-1/13), gdy tymczasem pozostałą zawartość wymienionych warstw stanowiły przemieszane kości. Ostatnie z nich, które można wiązać z funkcjonowaniem cmentarza w późnym okresie nowożytnym, zalegały poniżej wysokości 50,47-50,39 m n.p.m.

Mniejszą liczbę poziomów grobowych zarejestrowano w wykopie W-12/13, w którym odkryto 10 warstw nowożytnego cmentarza. Po-

\footnotetext{
${ }^{24}$ Przez to pojęcie należy rozumieć nie tylko poziomy zachowanych w całości pochówków, ale także warstwy zawierające luźne, przemieszane wtórnie kości w wyniku naruszenia ich przez wkopy (np. przy tworzeniu ossuariów) w różnych miejscach wokół kościoła.

${ }^{25}$ Przed zasypaniem jam grobowych przy głowie zmarłego wysypywano czasem węgielki drzewne z trybularza (Sulkowska-Tuszyńska, Górzyńska 2010, s. 45).

${ }^{26}$ Groby: G-10/13, G-12/13, G-13/13, G-14/13, G-15/13, G-16/13, G-18/13, G-21/13, G-22/13, G-23/13
} 
mimo pozornie dużej ich ilości, groby zachowane w stanie nienaruszonym odkryto jedynie $w$ trzech jednostkach (2., 3. i 4. poziom grobowy). Wszystkie pozostałe warstwy zapełniały luźne, przemieszane kości z grobów naruszonych podczas akcji budowlanej tzw. łącznika klasztornego. Podobnie było w wykopie W-8/11, w którym nietknięte pochówki odkryto tylko w 4., 5. i 6. poziomach grobowych ${ }^{27}$. Zawartość warstw cmentarza nowożytnego w obu wymienionych wykopach stanowiła szarobrunatna, spiaszczona próchnica. W najwyższych jednostkach przemieszana była ona $\mathrm{z}$ dużymi ilościami gruzu ceglanego i zaprawy, które znalazły się tam w związku z budową tzw. łącznika. Gruz i drobiny zaprawy zanikały w wykopach wraz z pojawieniem się pierwszych, nienaruszonych grobów. Typowe znaleziska, dzięki którym możliwe było przyporządkowanie opisywanych nawarstwień do cmentarza nowożytnego, to wianki grobowe, medalik z grobu G-47/13, ceramika i szkło z okresu nowożytnego, kafle ornamentowane i monety. W wykopie $\mathrm{W}-12 / 13$ odkryto sześć grobó ${ }^{28} \mathrm{w}$ trzech poziomach grobowych, a w wykopie W-8/11 trzy ${ }^{29}$ groby w jednym poziomie grobowym. Nawarstwienia cmentarza nowożytnego miały swoją górną granicę na wysokości około 50,50 m n.p.m. w wykopie W-8/11 i 50,95 m n.p.m. w wykopie W-12/13.

Pod względem ilości odkrytych pochówków nowożytnych wykop W-16/15 zajmuje trzecie miejsce. Wyodrębnić w nim można siedem poziomów cmentarza z omawianego okresu, których początek wyznacza pojawienie się pierwszych wianków grobowych i innych wyrobów związanych z tą epoką ${ }^{30}$ oraz wyraźnych śladów trumien. Na tym poziomie zalegały nawarstwienia silnie zawilgoconej, szarobrunatnej, spiaszczonej próchnicy z niewielkimi ilościami ceglanego gruzu, drobin zaprawy i niewielkimi węglami drzewnymi. Największe zagęszczenie pochówków wystąpiło $\mathrm{w}$ dolnych warstwach nowożytnego cmentarza, w których obecne były cztery groby ${ }^{31}$. Powyżej nich zale-

\footnotetext{
${ }^{27} \mathrm{~W}$ tym wykopie kości ludzkie odkryto jeszcze w poziomach grobowych 7.-12.

${ }^{28}$ Groby: G-47/13, G-56/13, G-37/13, G-34/13, G-41/13, G-44/13.

${ }^{29}$ Groby: G-33/11, G-34/11, G-35/11.

${ }^{30}$ Należą do nich fragmenty ceramiki i kafli, klamra od pasa, ćwieki mocujące tkaninę wewnątrz trumny, guziki, moneta i medalik.

${ }^{31}$ Groby: G-13/15, G-14/15, G-15/15, G-16/15.
} 
gała warstwa (12. poziom grobowy) z większymi ilościami ceglanego gruzu i zaprawy, zawierająca niewiele kości z naruszonych pochówków. Dopiero w jej górnej partii odkryto zachowany w układzie grób G-10/15. W wyższych poziomach cmentarza nowożytnego zalegało jeszcze pięć grobów ${ }^{32}$, najpłycej położony, G-1/15, wyznacza górną granicę nowożytnego cmentarza (około 50,60 m n.p.m.), powyżej której wyeksplorowano jedynie luźne szczątki kostne.

W wykopie W-4/10 nawarstwienia nowożytnej nekropolii zamykały się w poziomach grobowych 6.-11. Podobnie jak w przypadku opisanych poprzednio jednostek warstwy te składały się z szarobrunatnej, spiaszczonej próchnicy z małymi lub średnimi fragmentami gruzu ceglanego, drobinami zaprawy, otoczakami i warstwą spalenizny w górnych partiach. W poziomach grobowych eksplorowano zarówno luźne kości, jak i całe groby, których odkryto siedem ${ }^{33}$. Już w najniższych jednostkach obecne były fragmenty wianków grobowych i ślady trumien lub mar, a w wyższych nawarstwieniach także nowożytna ceramika naczyniowa. $Z$ analizy wyników badań wynika, że cmentarz w tym miejscu był zapełniony w mniejszym stopniu niż było to widoczne w pozostałych wykopach. W każdym z poziomów grobowych odsłaniano pojedyncze, rzadziej podwójne groby. Nienaruszone warstwy cmentarza nowożytnego leżą poniżej wysokości około 50,47 m n.p.m., powyżej której znajdował się ślad późniejszego wkopu.

Ostatnim wykopem uwzględnionym w analizie warstw cmentarnych jest wykop W-5/10. Mimo że głównym celem jego założenia było odsłonięcie fundamentu dawnego budynku klasztornego, również w tym wykopie uchwycono warstwy cmentarne, które skoncentrowane były w jego północnej części ${ }^{34}$. Zalegało $\mathrm{w}$ niej 13 grobów ${ }^{35} \mathrm{z}$ okresu nowożytnego, skupionych w czterech poziomach grobowych (5.-8.). Ich rozmieszczenie było dość równomierne $\mathrm{w}$ każdym $\mathrm{z}$ poziomów, a najwięcej pochówków zarejestrowano w 7. jednostce, w której było ich

\footnotetext{
${ }^{32}$ Groby: G-7/15, G-5/15, G-4/15, G-3/15, G-2/15, G-1/15.

${ }^{33}$ Groby: G-17/10, G-16/10, G-15/10, G-13/10, G-11/10, G-10/10, G-6/10.

${ }^{34}$ Część południowa stykała się bezpośrednio ze ścianą budynku, wobec czego nie odkryto w niej grobów.

${ }^{35}$ Groby: G-20/10, G-19/10, G-18/10, G-14/10, G-12/10, G-9/10, G-8/10, G-7/10, G-5/10, G-4/10, G-3/10, G-2/10, G-1/10.
} 
sześć. Zawartość warstw stanowiła brunatnoszara, spiaszczona próchnica, przemieszana ze średniej wielkości fragmentami gruzu ceglanego i zaprawy. Podobnie jak w przypadku poprzednich wykopów również tu podstawą wydzielenia nowożytnych warstw cmentarnych były znaleziska wianków grobowych, które w najniższym punkcie pojawiły się w 5. poziomie grobowym przy grobie G-20/10, ślady trumien (obecne od tego samego poziomu) oraz przedmioty, takie jak: fragmenty ceramiki nowożytnej i szkła, ćwieki pochodzące z trumien, fragmenty kafli, krzyżyk brązowy, fragment klamry od pasa i moneta - solid z datą emisji w 1693 r. Drugi zespół nawarstwień, związany z nowożytnym cmentarzem, rozpoczyna się w wykopie W-5/10 na wysokości 49,82 m n.p.m., a kończy na wysokości 50,54 m n.p.m., gdzie odkryto ostatni, zachowany w całości pochówek.

Ostatni, trzeci zespół jednostek w obrębie warstw cmentarnych przy kościele św. Jakuba tworzą te warstwy, które uformowały się w okresie między 1. połową XIX w. a XX w., w czasie przebudów i kolejnych remontów kościoła. W związku $\mathrm{z}$ tym, że wówczas nekropolia nie była użytkowana, w przypadku niektórych wykopów jednostki stratyfikacyjne przyporządkowane do tego zespołu nie zawierają ani grobów, ani też luźnych szczątków kostnych, lecz stanowią jedynie wierzchnie warstwy przykrywające starsze poziomy grobowe. Ich miąższość w każdym z wykopów była inna i wahała się od jednego metra do zaledwie kilkunastu centymetrów. Podobnie scharakteryzować można jednostki z przełomu 1. połowy XIX i XX w. zawarte w wykopie W-16/15, położonym na północny wschód od wykopu W-5/10. Tutaj także odnajdywano przemieszane kości, zalegające w warstwach 1.-4., zawierających silnie zawilgoconą, brunatnoszarą, spiaszczoną próchnicę. W górnych partiach zespołu III wystąpiły w tym miejscu duże ilości gruzu ceglanego i dachówkowego z zaprawą. Najgłębiej położona warstwa 4. znajdowała się na poziomie 50,60 m n.p.m., a najwyższy punkt tego zespołu (1. WM) leżał na wysokości 51,43 m n.p.m. Oznacza to, że miąższość wszystkich warstw wyniosła około 0,83 metra. Nie odkryto natomiast śladów użytkowania cmentarza $\mathrm{z}$ omawianego okresu w miejscu założenia wykopów W-12/13 i W-8/11, gdyż położone są one na obszarze funkcjonowania tzw. łącznika klasztornego. W związku z tym 
teren ten nie mógł być użytkowany jako cmentarz już od 1667 r., gdy rozpoczęto akcję budowlaną wspomnianego korytarza. Warstwy należące do zespołu III miały w tych punktach około 0,54 m (W-12/13) i $0,25 \mathrm{~m}(\mathrm{~W}-8 / 11)$, a znajdowały się na wysokościach od 50,95 do 51,49 m n.p.m. (W-12/13) i od 51,50 do 51,75 m n.p.m. (W-8/11).

\section{Kaplice przy południowej ścianie kościoła}

Zagadnieniem budowy kaplic przy kościele św. Jakuba, powstających od około połowy XIV do XVI w., zajmowało się w przeszłości kilku badaczy. Autorem najnowszej pracy, w której zebrane zostały dotychczasowe, najważniejsze ustalenia na ten temat, jest Aleksander Konieczny (Konieczny 2010, s. 91-120). Wymienia on w swoim artykule nazwiska wszystkich naukowców, którzy tworzyli własne założenia odnośnie do budowy kaplic oraz opisuje wyniki badań architektonicznych i dendrochronologicznych, których był współautorem. Jednym z celów badań archeologicznych w 2015 r. była weryfikacja hipotezy Koniecznego na temat bocznego wejścia do kościoła, w miejscu którego w późniejszym czasie wybudowano kaplicę św. Walentego. Dzięki założeniu wykopu W-16/15 (ryc. 3, ryc. 6) możliwe było odsłonięcie fundamentu ściany kaplicy w tym miejscu i eksploracja warstw cmentarza średniowiecznego i nowożytnego. Wydobyto 22 warstwy mechaniczne, które można połączyć w trzy zespoły. W pierwszym, zamykającym się w jednostkach 22.-12., najstarsze są warstwy związane $\mathrm{z}$ budową kościoła i początkowym okresem użytkowania cmentarza średniowiecznego w tym miejscu. Zgodnie z ustaleniami Krystyny Sulkowskiej-Tuszyńskiej ${ }^{36}$ jego chronologię można określić na czas od lat trzydziestych XIV w. do lat trzydziestych/czterdziestych XV w. W wykopie odsłonięto stopę fundamentową kamienno-ceglanego fundamentu kaplicy św. Walentego, położoną najgłębiej na wysokości 48,65 m n.p.m. Nad nim znajdowała się arkada fundamentowa. Fundament zbudowany został z rzędu kamieni polnych zalanych zaprawą

\footnotetext{
${ }^{36}$ Materiały pokonferencyjne z VIII Konferencji Sprawozdawczej z badań archeologicznych w województwie kujawsko-pomorskim w latach 2015-2016, wygłoszone 25 maja 2017 r. w Biskupinie (zob. Bibliografia).
} 
z drobnym gruzem ${ }^{37}$. Ceglana ściana jest wysunięta w stosunku do arkady i wymurowana w regularnym wątku polskim. Odsłonięto również kamienno-ceglany fundament przypory nawy południowej, którą przedłużono podczas budowy kaplicy św. Walentego. Wykonany był on $\mathrm{z}$ bardzo dużych kamieni, zalanych dużą ilością zaprawy z gruzem ceglanym, a jego stopa znajdowała się na wysokości 48,70 m n.p.m. Przyporę wspierają wielkie kamienie węgłowe, które wystawały $20 \mathrm{~cm}$ przed jej lico, stanowiąc rodzaj odsadzki. Wymurowano ją częściowo w wątku polskim i gotyckim. W trakcie budowy kaplicy postawiono nową przyporę, wspierającą jej południową ścianę na osi. Przypora opiera się na warstwie kamieni (znacznie mniejszych niż w poprzednio opisanym fundamencie), zalanych dużą ilością zaprawy $z$ grubym gruzem ceglanym, jednak jej fundament sięga tylko wysokości 50,50 m n.p.m. Przyporę wzniesiono $\mathrm{z}$ cegieł $\mathrm{z}$ kamieniami w środku (do wysokości 50,90 m n.p.m.) w mieszanym wątku. Stopa fundamentu, wysuniętego przed lico przypory o $30 \mathrm{~cm}$, leży na wysokości $48,50 \mathrm{~m}$ n.p.m.

Drugi zespół warstw obejmuje jednostki 11.-5. i rozpoczyna się na wysokości 49,66 m n.p.m., tj. na poziomie, w którym swój początek mają pochówki nowożytne. Można go datować na czas od lat trzydziestych/czterdziestych XV w. do 1. połowy XIX w. Główne odkrycie, związane $\mathrm{z}$ architekturą kościoła, stanowi ceglany fundament arkadowy o łagodnym łuku, rozpięty między przyporami. Miał on grubość około 40 centymetrów, jego dolna powierzchnia znajdowała się na wysokości 50,32 m n.p.m., a górna na wysokości 50,80 m n.p.m. Podłucze tej konstrukcji, nieposiadającej regularnego wątku, mierzyło około 75 centymetrów, a opór dla niej wykonano, wcinając się w kamienny fundament trzeciej od wschodu przypory, od zachodu wspierając ją murkiem ceglanym. Pod arkadą znajdowała się wnęka wypełniona warstwami brunatnoszarej, spiaszczonej próchnicy z gruzem ceglanym. W tej przestrzeni odnaleziono trzy groby.

Najwyżej położony, trzeci zespół stratyfikacyjny tworzą jednostki 4.-1. (niwelacje: od 50,60 do 50,43 m n.p.m.), które uformowały się w okresie od połowy XIX do XX w. w związku z wykonywaniem tu wkopów i remontami kościoła. Konsekwencją tych prac jest zaleganie

${ }^{37} \mathrm{~W}$ podobny sposób skonstruowano fundamenty tzw. łącznika. 
w warstwach tego zespołu bardzo dużych ilości ceglanego i dachówkowego gruzu. Wkopy z przełomu XIX i XX w. zniszczyły w tym miejscu wiele nowożytnych pochówków, wobec czego w poziomach 1.-4. odnajdywano sporo luźnych kości. Wierzchnią warstwę zespołu III stanowi żółty piasek, rozprowadzony wokół kościoła w XX w., i przykrywająca go kamienna płyta nagrobna.

\section{Klasztor cysterek-benedyktynek}

Nawarstwienia związane z klasztorem benedyktynek zostały zarejestrowane w wykopie W-5/10 (ryc. 3, ryc. 6). Ich analiza pozwala wyróżnić dwa zespoły nawarstwień, które powstały w tym miejscu od rozpoczęcia budowy dawnego zespołu klasztornego aż do XX w. Budowa ta mogła się rozpocząć już w 1. połowie XIV w., w momencie, gdy mniszki otrzymały patronat nad kościołem św. Jakuba, jeżeli zamieszkiwały wówczas w pobliżu nowomiejskiej świątyni (Cicha 2010, s. 142, Cicha 2013, s. 75).

Pierwszy zespół warstw tworzą jednostki formujące się od początkowego okresu użytkowania kwartału kościelnego i budowy klasztoru, tj. od około połowy XIII/końca XIV w. do połowy XIX w. Za przyjęciem takiego datowania przemawiają wyniki badań radiowęglowych, przeprowadzonych na próbce drewna pozyskanej z dolnych partii fundamentu, które wskazały na taką ich chronologię (Cicha 2011, s. 194, Cicha 2013, s. 76-77). Opisywany zespół obejmowały warstwy mechaniczne 19.-14. Zarejestrowano w nim stopę fundamentu budynku poklasztornego, położoną na wysokości $47,88 \mathrm{~m}$ n.p.m., $3,85 \mathrm{~m}$ poniżej dzisiejszego poziomu gruntu. Fundament zbudowany był $\mathrm{z}$ ułożonych na dnie wkopu bardzo dużych kamieni, na których położono drugą warstwę kamieni łączonych zaprawą. Miał on także cztery ceglane odsadzki, położone na wysokościach (od najniższej): 1. 48,50 m n.p.m., 2. 48,71 m n.p.m., 3. 49,14 m n.p.m., 4. 49,25 m n.p.m. Zespół I miał miąższość około $1,42 \mathrm{~m}$ i zalegał $\mathrm{w}$ warstwach jasnożółtego piasku $\mathrm{z}$ kamieniami otoczakowymi $\mathrm{w}$ dolnych partiach, rdzawożółtego piasku z kamieniami, drobinami gruzu ceglanego, węgielkami drzewnymi i luźnymi kośćmi w części środkowej oraz szarobrunatnej, spiaszczo- 
nej próchnicy z zachowanymi grobami w partii górnej. Nawarstwienia te kończyły się na wysokości około 49,30 m n.p.m., w miejscu zakończenia XIX-wiecznego wkopu, który otwierał kolejny, drugi zespół warstw. Wspomniany wkop wykonano w XIX w. przy murze dawnego klasztory w celu pokrycia fundamentu warstwą izolacji, zabezpieczającej go przed wilgocią. Jego początek ma miejsce już na współczesnym poziomie gruntu (51,57 m n.p.m.), a zawartość stanowi szarobrunatna, spiaszczona próchnica z bardzo dużymi ilościami gruzu ceglanego i kości ze zniszczonych grobów w warstwach 1.-7. Zespół II obejmował jednostki 14.-1. W trakcie odsłaniania muru okazało się, że jest on pokryty mieszaniną zaprawy murarskiej i smoły. Fakt ten uniemożliwił obserwację całej ściany, ponieważ ze względów konserwatorskich możliwe było jedynie wykonanie pasa odkrywki o wymiarach 120 x 40 centymetrów. Dzięki temu ustalono, że budynek wymurowano w wątku gotyckim z takich też cegieł o wymiarach $9 \times 13$ x 27 centymetrów, co pozwala potwierdzić, że powstał on na przełomie XIII i XIV w. (Cicha 2011, s. 194). W związku z opisanymi spostrzeżeniami można datować powstanie wymienionych warstw na okres między połową XIX a XX w.

\section{Tzw. łącznik klasztorny}

Podczas badań archeologicznych wokół kościoła św. Jakuba kilkakrotnie zakładano wykopy mające na celu odsłonięcie reliktów architektury tzw. łącznika klasztornego, czyli przejścia łączącego budynki zespołu klasztornego z kościołem. Dwa z nich, położone po stronie południowej wykopy W-8/11 (ryc. 3) i W-12/13 (ryc. 3, ryc. 7), zostały wzięte pod uwagę $\mathrm{w}$ niniejszej analizie. W pierwszym $\mathrm{z}$ wymienionych odkryto zachodnią ścianę łącznika, a w drugim wyeksplorowano obie ściany korytarza wraz z warstwą ceglanej posadzki. Istnieje możliwość połączenia wydobytych jednostek w cztery zespoły stratyfikacyjne, które narastały w kolejnych okresach użytkowania terenu przykościelnego, co pozwala wyznaczyć przynajmniej przybliżoną chronologię tych nawarstwień przy uwzględnieniu ich charakteru i zawartości. 
Do I zespołu jednostek należy zaliczyć warstwy związane z początkowym użytkowaniem kwartału kościelnego oraz funkcjonowaniem średniowiecznego cmentarza między przełomem XIII i XIV a przełomem XV i XVI w. Zawierały one w dolnych partiach rdzawy i żółty piasek z kamieniami otoczakowymi, a w górnych szarobrunatną, spiaszczoną próchnicę, która w wykopie $\mathrm{W}-8 / 11$ przemieszana była ze średnimi ilościami ceglanego gruzu i drobin zaprawy. W tym samym wykopie zespół I zamykał się w warstwach 18.-11. i leżał na wysokości od 48,60 m n.p.m. do 49,85 m n.p.m. W przypadku wykopu W-12/13 były to warstwy 17.-14. i niwelacje od 49,00 m n.p.m. do 49,70 m n.p.m.

II zespół warstw tworzą jednostki, które zawierają nienaruszone groby z okresu nowożytnego - od przełomu XV i XVI w. do rozpoczęcia akcji budowlanej łącznika klasztornego po 1667 r. Pierwotnie warstwy nowożytnych pochówków znajdowały się na wyższym poziomie, jednak w wyniku prac budowlanych zostały one zniszczone. Wszystkie jednostki składały się z szarobrunatnej, spiaszczonej próchnicy, która w wykopie W-8/11 zmieszana była z ceglanym gruzem i drobinami zaprawy. W tym miejscu zespół II tworzyły warstwy 10.-9., które leżały na poziomie od 49,70 m n.p.m. do 50,03 m n.p.m. i zawierały zarówno nienaruszone lub przecięte wkopem fundamentowym groby, jak też liczne kości z wtórnie przemieszanych pochówków. Z kolei w wykopie W-12/13 do zespołu należały jednostki 14.-12., wyłącznie $\mathrm{z}$ zachowanymi $\mathrm{w}$ układzie anatomicznym szkieletami. Leżały one na wysokości od 49,70 m n.p.m. do 49,90 m n.p.m., czyli przybliżonego poziomu położenia stopy fundamentowej ścian łącznika w tym miejscu.

III zespół stanowią warstwy, które formowały się od około 3/4 ćwierci XVII w., gdy ułożono posadzkę wewnątrz łącznika, do czasu po 1833 r., gdy budynek został zburzony. Posadzka została uchwycona jedynie w wykopie W-12/13, którego warstwy 12.-4. ukształtowały się podczas budowy ścian i podłogi korytarza. W tym czasie zniszczonych zostało wiele grobów z okresu nowożytnego, których pozostałość stanowią liczne znaleziska luźnych kości z towarzyszącymi im przedmiotami pochodzącymi z cmentarza i określającymi jego chronologię. Jednostki tego kompleksu składały się z szarobrunatnej, a w części zachodniej z ciemnoszarobrunatnej, spiaszczonej próchnicy. W niższych par- 
tiach zawierały one małe i średnie, a w wyższych duże ilości ceglanego gruzu z zaprawą. Zespół ten znajduje się w wykopie W-12/13 na wysokości od 49,90 m n.p.m. do około 51,25 m n.p.m. (najwyższy punkt położenia posadzki). Warstwy wchodzące w jego skład, znajdujące się poniżej posadzki, powstały nie tylko w czasie funkcjonowania cmentarza w latach pierwszej obecności benedyktynek przy kościele. Zapewne używany był on również $\mathrm{w}$ tzw. okresie protestanckim z lat 1557-1667, gdy zarząd kościoła należał do gminy ewangelickiej. Niestety, groby $\mathrm{z}$ warstw $11 .-5$. zostały bezpowrotnie zniszczone po $1667 \mathrm{r}$. Podobny charakter miały jednostki 10.-2. z wykopu W-8/11, które zawierały luźne szczątki kostne $\mathrm{z}$ pochówków naruszonych podczas budowy łącznika. W tym miejscu nie odkryto jednak reliktów posadzki, którą prawdopodobnie w całości rozebrano po 1833 r. Zespół III zamykał się tu w poziomach od 49,85 m n.p.m. do 51,50 m n.p.m.

IV zespół tworzą jednostki, które powstały od lat trzydziestych XIX w. do XX w., gdy na terenie wokół kościoła ułożono płyty chodnikowe. Stanowią go warstwy szarobrunatnej i ciemnoszarobrunatnej, spiaszczonej próchnicy $\mathrm{z}$ bardzo licznymi, dużymi fragmentami ceglanego gruzu z zaprawą, pochodzącymi z rozbiórki łącznika po $1833 \mathrm{r}$., których użyto do wyrównania terenu wokół kościoła. Najmłodszemu zespołowi stratyfikacyjnemu nie towarzyszyły żadne znaleziska. W wykopie W-8/11 należała do niego warstwa 1., leżąca na wysokości od 51,50 m n.p.m. do 51,75 m n.p.m., a wykopie W-12/13 jednostki 3.-1., położone na wysokości od 51,32 m n.p.m. do 51, 49 m n.p.m.

\section{Podsumowanie}

Powyższe obserwacje stanowią przegląd odsłoniętych w sześciu wykopach nawarstwień, pogrupowanych w cztery kompleksy. W obrębie każdego z nich udało się wyróżnić zespoły stratyfikacyjne, których chronologia określona została poprzez odpowiednią interpretację zawartości warstw i obserwację relacji zachodzących pomiędzy nimi. Jednocześnie zespoły oznaczone tymi samymi numerami otrzymały zbliżone datowanie. $W$ ten sposób udało się ustalić, w jakim czasie formowały się kolejne zespoły nawarstwień oraz w jaki sposób były one 
użytkowane. Przy realizacji tak określonych założeń wykorzystano dokumentację archeologiczną z wszystkich sezonów badawczych, stanowiącą główne źródło informacji na temat odkryć w każdym wykopie. Użycie ich pozwoliło na stworzenie analizy nawarstwień między kościołem św. Jakuba a dawnym klasztorem. Należy przy tym pamiętać, że badania archeologiczne nie zostały przeprowadzone w każdym obszarze kościoła ${ }^{38}$, w związku z czym nie jest możliwe wyciąganie zbyt daleko idących wniosków. Jednak dla lepszego poznania historii kościoła św. Jakuba i klasztoru cysterek-benedyktynek niezbędne wydaje się kontynuowanie badań, które $\mathrm{z}$ różnych względów nie są prowadzone od $2015 \mathrm{r}$.

\section{Bibliografia}

Birecki P., Kościót pw. św. Jakuba światynia protestancka Nowego Miasta Torunia, [w:] Dzieje i skarby kościoła świętojakubskiego w Toruniu, red. K. Kluczwajd, Toruń 2010.

Cicha A., Klasztor cysterek-benedyktynek przy kościele pw. św. Jakuba w Toruniu $w$ świetle źródet ikonograficznych $i$ archeologicznych, [w:] Dzieje i skarby kościoła świętojakubskiego w Toruniu, red. K. Kluczwajd, Toruń 2010.

Cicha A., Niełatwe odkrywanie klasztoru toruńskich cysterek-benedyktynek, czyli o badaniach archeologiczno-architektonicznych z lat 2008-2010, [w:] Forum Scientiae Cisterciense. Przyszłość badań nad historia i kultura cysterska $w$ Polsce, red. E. Łużyniecka, A. Galar, Wrocław 2011.

Cicha A., Domy zakonne zamykaja się, maja ścisła klauzurę (...), aby siostry (...) przyzwoitość zakonna jak najprzykładniej zachowywaty-tzw. łacznik nowożytny między klasztorem a kościołem św. Jakuba Apostoła w świetle badań archeologiczno-architektonicznych, [w:] Stare i nowe dziedzictwo Torunia. Studia i materiaty z dziedzictwa kulturowego Torunia i regionu, t. 1, red. J. Raczkowski, Torun 2013.

Drążkowska A., Wianki wydobyte z krypty grobowej w kościele pw. Wniebowzięcia Najświętszej Marii Panny w Toruniu, Rocznik Toruński, t. 33, 2006.

Konieczny A., Historia budowy kaplic przy kościele pw. św. Jakuba w Toruniu $w$ świetle najnowszych badań architektonicznych $i$ dendrochronolo-

\footnotetext{
${ }^{38} \mathrm{~Np}$. nigdy nie umożliwiono ich wykonania wewnątrz świątyni.
} 
gicznych, [w:] Dzieje i skarby kościoła świętojakubskiego w Toruniu, red. K. Kluczwajd, Toruń 2010.

Krantz-Domasłowska L., Domasłowski J., Kościół świętego Jakuba w Toruniu, Toruń 2001.

Sulkowska-Tuszyńska K., Apud Terram, Ante Ecclesiam. Niezapisane karty historii kościoła $i$ parafii św. Jakuba w Toruniu, Pomorania Antiqua, t. XXIII, 2010.

Sulkowska-Tuszyńska K., Cicha A., Dawny klasztor przy kościele św. Jakuba $w$ Toruniu i jego otoczenie $w$ świetle badań archeologicznych z lat 2008 2009, Rocznik Toruński, t. 37, 2010.

Sulkowska-Tuszyńska K., Górzyńska A., Dawne cmentarze nowomiejskie $w$ świetle badań archeologicznych, [w:] Cmentarz św. Jakuba i inne chrześcijańskie cmentarze nowomiejskie, red. K. Mikulski, Toruń 2010.

Prace niepublikowane

Sulkowska-Tuszyńska K., Pod toruńskim kościołem św. Jakuba. Odkrycia w 2015 roku, referat wygłoszony na VIII Konferencji Sprawozdawczej $\mathrm{z}$ badań archeologicznych $\mathrm{w}$ województwie kujawsko-pomorskim w latach 2015-2016, 25 maja 2017 r., Biskupin.

Sulkowska-Tuszyńska K., Sprawozdanie z badań archeologiczno-architektonicznych przy kościele św. Jakuba Apostoła w Toruniu w 2010 roku, Toruń 2011 (Archiwum IA UMK, Toruń).

Sulkowska-Tuszyńska K., Sprawozdanie z badań archeologiczno-architektonicznych przy kościele św. Jakuba Apostoła w Toruniu w 2011 roku, Toruń 2012 (Archiwum IA UMK, Toruń)

Sulkowska-Tuszyńska K., Sprawozdanie z badań archeologiczno-architektonicznych przy kościele św. Jakuba Apostoła w Toruniu w 2013 roku, Toruń 2014 (Archiwum IA UMK, Toruń).

Sulkowska-Tuszyńska K., Sprawozdanie z nadzoru archeologicznego przy klasztorze cysterek-benedyktynek w latach 2008-2009, Toruń 2010 (Archiwum IA UMK, Toruń).

Dzienniki badań wykopów: W-4/10, W-5/10, W-8/11, W-12/13, W-14/13, W$16 / 15$.

Dokumentacja rysunkowa profili i rzuty płaskie wykopów: W-4/10, W-5/10, W-8/11, W-12/13, W-14/13, W-16/15.

Dokumentacja fotograficzna wykopów: W-4/10, W-5/10, W-8/11, W-12/13, W-14/13, W-16/15. 